\title{
PENGARUH NPL DAN BOPO TERHADAP ROA PADA SEKTOR BANK BUMN PERIODE 2015-2020
}

\author{
Habibah S. Fauziyyah', Nurismalatri ${ }^{2}$ \\ Fakultas Ekonomi, Universitas Pamulang \\ Email : habibahsulaiman1406@gmail.com
}

\begin{abstract}
Purpose. This study aims to determine the effect of Non-Performing Loans (NPL) and Operating Costs (BOPO) on the profitability of state-owned banks in Indonesia, which is proxied by Return On Assets (ROA). The population in this study is the financial statements of state-owned banks listed on the Indonesia Stock Exchange (BEI) for the 2015-2020 period.

Methods. The sample in this study is a company report in the form of a balance sheet and profit and loss from state-owned banks for the 2015-2020 period. The analysis technique used is panel data regression. The data processing stage of this research was carried out using Eview 9 software.

Findings. The results of simultaneous hypothesis testing (F test) NPL and BOPO together have a significant effect on ROA with $f_{\text {count }}$ of $147.5253>f_{\text {table }}$ of 4.30 with a significant value of $0.000000<0.05$. While partially ( $t$ test) the NPL variable has no effect on ROA with the results of $t_{\text {count }} 0.576915<t_{\text {table }} 2.07961$ with a significant value of $0.5701>0.05$. The results of the BOPO variable show that partially ( $t$ test) $t_{\text {count }}-8.497554>t_{\text {table }} 2.10982$ with a significant value of $0.000000<0.05$ (significant negative effect). The result of degree of determination (Adjusted $R$ Square) in panel data is 0.933555, this shows that the independent variables, namely NPL and BOPO have an effect on ROA of 93.35\% while the remaining $6.65 \%$ is influenced by other factors that are not explained in this study.
\end{abstract}

\section{Keywords : Non-Performing Loan, BOPO, Return On Asset.}

\begin{abstract}
ABSTRAK
Tujuan. Penelitian ini bertujuan untuk mengetahui pengaruh Non-Performing Loan (NPL) dan Biaya Operasional Pendapatan Operasional (BOPO) terhadap profitabilitas bank BUMN di Indonesia yang diproksikan dengan Return On Assets (ROA). Populasi dalam penelitian ini adalah laporan keuangan Bank BUMN yang terdaftar di Bursa Efek Indonesia (BEI) periode 2015-2020.
\end{abstract}

Metode. Sampel dalam penelitian ini laporan perusahaan berupa neraca dan laba rugi dari bank BUMN periode 2015-2020. Teknik analisis yang digunakan adalah regresi data panel. Tahap pengolahan data penelitian ini dilakukan menggunakan perangkat lunak Eview 9.

Hasil. Dari hasil uji hipotesis secara parsial (uji t) variabel NPL tidak berpengaruh terhadap ROA dengan hasil $t_{\text {hitung }} 0.576915<t_{\text {tabel }} 2.07961$ dengan nilai signifikan $0.5701>$ 0.05 . Hasil variabel BOPO menunjukkan bahwa secara parsial (uji $t$ ) $t_{\text {hitung }}-8.497554>t_{\text {tabel }}$ 2.10982 dengan nilai signifikan sebesar $0.000000<0.05$ (berpengaruh negatif signifikan). Sedangkan hasil uji hipotesis simultan (uji F) NPL dan BOPO secara bersama-sama berpengaruh signifikan terhadap ROA dengan $\mathrm{f}_{\text {hitung }}$ sebesar $147.5253>\mathrm{f}_{\text {tabel }}$ sebesar 4.30 dengan nilai signifikan $0.000000<0.05$. Hasil derajat determinasi (Adjusted R Square) pada data panel adalah sebesar 0.933555 hal ini menunjukkan bahwa variabel 
independen yaitu NPL dan BOPO berpengaruh terhadap ROA sebesar 93,35\% sedangkan sisanya sebesar $6,65 \%$ dipengaruhi oleh faktor lain yang tidak dijelaskan dalam penelitian ini.

\section{Kata Kunci : NPL, BOPO, ROA.}

\section{Pendahuluan}

Bank Umum menurut Undang-Undang RI Nomor 7 tahun 1992 tentang perbankan sebagaimana diperbaharui dengan UU nomor 10 tahun 1998, merupakan badan usaha yang menghimpun dana dari masyarakat dalam bentuk simpanan dan menyalurkannya kepada masyarakat dalam bentuk kredit dan atau bentuk-bentuk lainnya dalam rangka meningkatkan taraf hidup masyarakat.

Lembaga keuangan perbankan milik pemerintah atau disebut juga Bank BUMN (Badan Usaha Milik Negara) merupakan bank yang biasanya dipilih untuk menjalankan program pemerintah diantaranya yaitu Bank Negara Indoesia (BBNI), Bank Rakyat Indonesia (BBRI), Bank Tabungan Negara (BBTN), dan Bank Mandiri (BMRI). Aktivitas utama dalam perbankan ialah menghimpun dana dari masyarakat, agar masyarakat mau menyimpan uangnya di bank maka pihak perbankan memberikan imbalan balas jasa yang berupa bunga, bagi hasil, hadiah, pelayanan dan lainnya. Setelah memperoleh dana dalam bentuk simpanan dari masyarakat, maka dana tersebut diputarkan kembali ke masyarakat dalam bentuk pinjaman atau kredit.

Kinerja keuangan bank merupakan tingkat efisiensi dan produktivitas yang dilakukan secara berkala atas dasar laporan manajemen dan laporan keuangan (Ningtyas, dkk : 2013). Dalam mengukur tingkat kinerja keuangan dapat dilakukan dengan menggunakan rasio profitabilitas sebagai indikator yang paling tepat dalam mengukur kinerja bank tersebut. Semakin tinggi profitabilitas maka semakin baik kinerja keuangan bank. ROA merupakan salah satu indikator yang digunakan dalam mengukur tingkat profitabilitas yang dimana menurut Kasmir (2017), ROA ini dapat digunakan untuk menilai kemampuan bank dalam memperoleh keuntungan

Banyak faktor yang dapat mempengaruhi ROA berdasarkan penelitian Dewi (2018), Christiano dkk (2014) diantaranya yaitu persentase permasalahan kredit dari rasio NonPerforming Loan (NPL) dan persentase perbandingan biaya operasional dengan pendapatan operasional (BOPO). Dalam peraturan Bank Indonesia No 17/11/PBI/2015 tanggal 25 Juni 2015 suatu bank dapat dimasukkan dalam kategori yang sehat apabila nilai NPL memiliki rasio tidak lebih dari 5\% dan menurut ketetapan Bank Indonesia Nomor 6/10/PBI/2004 suatu bank yang memiliki nilai BOPO tidak lebih dari $93,5 \%$ termasuk kategori yang sehat. Berikut ini merupakan tabel perkembangan rasio keuangan perbankan BUMN periode 2015 sampai dengan 2019.

Tabel 1. Perkembangan Kinerja Bank BUMN

\begin{tabular}{|c|c|c|c|c|c|c|c|}
\hline \multicolumn{2}{|c|}{ Indikator } & 2015 & 2016 & 2017 & 2018 & 2019 & 2020 \\
\hline \multirow{3}{*}{ BBNI } & NPL & $2,70 \%$ & $3,00 \%$ & $2,30 \%$ & $1,90 \%$ & $2,30 \%$ & $4,30 \%$ \\
\cline { 2 - 8 } & BOPO & $75,50 \%$ & $73,60 \%$ & $71,00 \%$ & $70,10 \%$ & $73,20 \%$ & $93,30 \%$ \\
\cline { 2 - 8 } & ROA & $2,60 \%$ & $2,70 \%$ & $2,70 \%$ & $2,80 \%$ & $2,40 \%$ & $0,50 \%$ \\
\hline \multirow{3}{*}{ BBRI } & NPL & $2,02 \%$ & $2,03 \%$ & $2,10 \%$ & $2,14 \%$ & $2,62 \%$ & $2,94 \%$ \\
\cline { 2 - 8 } & BOPO & $67,96 \%$ & $68,93 \%$ & $69,14 \%$ & $68,48 \%$ & $70,10 \%$ & $81,22 \%$ \\
\cline { 2 - 8 } & ROA & $4,19 \%$ & $3,84 \%$ & $3,69 \%$ & $3,68 \%$ & $3,50 \%$ & $1,98 \%$ \\
\hline \multirow{2}{*}{ BBTN } & NPL & $3,42 \%$ & $2,84 \%$ & $2,66 \%$ & $2,82 \%$ & $4,78 \%$ & $4,37 \%$ \\
\cline { 2 - 8 } & BOPO & $84,83 \%$ & $82,48 \%$ & $82,06 \%$ & $85,58 \%$ & $98,12 \%$ & $91,61 \%$ \\
\hline
\end{tabular}




\begin{tabular}{|c|c|c|c|c|c|c|c|}
\hline \multicolumn{2}{|c|}{ Indikator } & 2015 & 2016 & 2017 & 2018 & 2019 & 2020 \\
\hline \multirow{3}{*}{ BMRI } & ROA & $1,61 \%$ & $1,76 \%$ & $1,71 \%$ & $1,34 \%$ & $0,13 \%$ & $0,69 \%$ \\
\cline { 2 - 8 } & NPL & $2,29 \%$ & $3,96 \%$ & $3,45 \%$ & $2,79 \%$ & $2,39 \%$ & $3,29 \%$ \\
\cline { 2 - 8 } & BOPO & $69,67 \%$ & $80,94 \%$ & $71,78 \%$ & $66,48 \%$ & $67,44 \%$ & $80,03 \%$ \\
\cline { 2 - 8 } & ROA & $3,15 \%$ & $1,95 \%$ & $2,57 \%$ & $3,17 \%$ & $3,03 \%$ & $1,64 \%$ \\
\hline
\end{tabular}

Sumber : Laporan Keuangan (2020)

Berdasarkan table diatas, dapat diketahui bahwa Bank BUMN selama kurun waktu 6 tahun terakhir baik bank BNI, BRI, BTN dan Bank mandiri mengalami penurunan ROA pada tahun 2019. Berdasarkan dari laporan tahunan yang diterbitkan bank BUMN dinyatakan bahwa hal ini disebabkan oleh penurunan margin di tahun 2019.

Adanya kondisi pandemic covid pada tahun 2020 juga akan dapat berdampak pada tingkat kesehatan perbankan yang mana meningkatnya masalah kredit macet yang diakibatkan penurunan ekonomi di Indonesia.

Dengan kondisi kinerja profitabilitas yang menurun, berarti bahwa harus diadakannya evaluasi kinerja dengan menganalisis keuangan dengan ukuran rasio yang menghubungkan dengan data keuangan. Analisis pada data keuangan dilakukan karena hal ini tentu saja dapat mengakibatkan bank mengalami permasalahan keuangan.

\section{Kajian Pustaka dan Hipotesis Literatur Review}

Secara sederhana bank diartikan oleh Kasmir (2018:24) sebagai lembaga keuangan dengan kegiatan usaha menghimpun dana dari masyarakat dan menyalurkan kembali dana tersebut ke masyarakat serta memberikan jasa-jasa bank lainnya, yang mana dalam pengelolaannya dibutuhkan manajemen keuangan yang baik.

Manajemen keuangan menurut Husnan dan Pudjiastuti (2015:6) meliputi manajemen pendanaan, baik yang berkaitan dengan suatu pengalokasian dana dalam bermacam bentuk investasi secara efektif maupun suatu usaha pengumpulan dana untuk pembiayaan investasi atau pembelanjaan secara efisien dengan tujuan memaksimumkan nilai perusahaan. Sutrisno (2013) menambhakan bahwa kegiatan ini digunakan oleh manajer keuangan sebagai bahan pengambilan keputusan dalam hal investasi, pendanaan, dan kebijakan dividen. Pengambilan keputusan ini dapat dilakukan dengan mempertimbangkan informasi yang berasal dari laporan keuangan dan juga sebagai cerminan prestasi yang dicapai perusahaan dalam suatu periode tertentu dalam melihat tingkat kesehatan perusahaan tersebut.

Informasi kinerja lainnya yang berasal dari laporan keuangan berupa rasio keuangan yang dapat melihat hasil kinerja dari suatu perusahaan adalah rasio profitabilitas yang menunjukan persentase keuntungan (net margin) yang diperoleh perusahaan sehubungan dengan keseluruhan sumber daya atau rata-rata jumlah asset atau sering disebut juga sebagai rasio ROA (Return On Assets).

Faktor indikator yang dapat dilakukan untuk memperoleh ROA yang baik dapat terlihat dari Non-Performing Loan (NPL) dan Biaya Operasional Pendapatan Operasional (BOPO). NonPerforming Loan (NPL) menurut Kasmir (2018) merupakan kredit bermasalah dan salah satu rasio yang berguna untuk menilai kualitas kinerja bank yang dapat diartikan NPL (Non Performing Loan) merupakan indikasi adanya masalah dalam bank tersebut yang mana jika tidak segera mendapatkan solusi maka akan berdampak bahaya pada bank.

BOPO yang menjadi proxy efisiensi operasional seperti yang biasa digunakan oleh Bank Indonesia dalam menghadapi berbagai macam resiko perbankan. BOPO ini diartikan oleh Kasmir (2014) sebagai upaya bank untuk meminimalkan salah satu resiko yaitu resiko 
operasional, yang merupakan ketidakpastian mengenai kegiatan usaha bank yang dapat dikarenakan kemungkinan resiko operasional berasal dari kerugian operasional bila terjadi penurunan keuntungan yang dipengaruhi oleh struktur biaya operasional bank, dan kemungkinan terjadinya kegagalan atas jasa dan produk yang ditawarkan

Penelitian pada NPL yang dilakukan oleh Dewi (2018), Yuliana (2014), Christiano dkk (2014), Warsa dkk (2016) dinyatakan dalam hasil penelitiannya bahwa NPL berpengaruh negatif secara signifikan terhadap ROA, yang mana diartikan bahwa setiap penurunan nilai NPL akan meningkatkan nilai kinerja perusahaan (ROA).

Sedangkan hasil penelitian dari Nurismalatri (2019), Dewi (2018), Christiano dkk (2014), Pratiwi dkk (2015), Sabir dkk (2012) menunjukkan bahwa BOPO berpengaruh negatif signifikan yang mana setiap penurunan BOPO akan meningkatkan kualitas profitabilitas perusahaan.

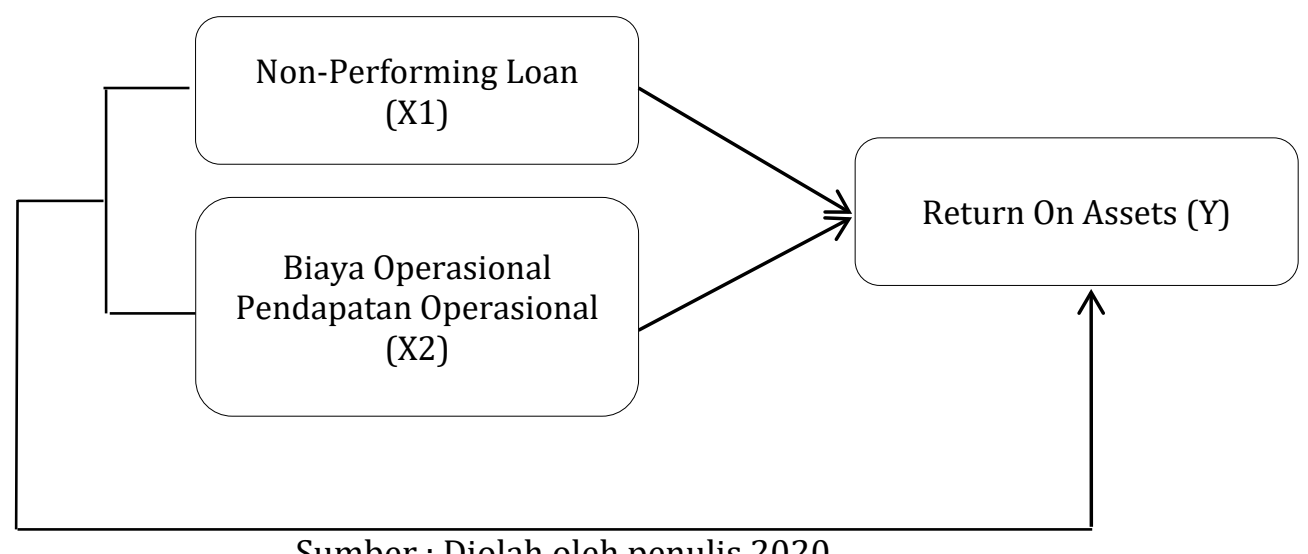

Sumber : Diolah oleh penulis 2020

\section{Gambar 1. Model Penelitian}

\section{Hipotesis}

Dari pendahuluan dan literatur review dapat di ajukan hipotesis penelitian sebagai berikut :

1) $\mathrm{H}_{0}$ : NPL berpengaruh signifikan terhadap ROA.

$\mathrm{H}_{1} \quad$ : NPL tidak berpengaruh signifikan terhadap ROA.

2) $\mathrm{H}_{0}$ : BOPO berpengaruh signifikan terhadap ROA.

$\mathrm{H}_{1}$ : BOPO tidak berpengaruh signifikat terhadap ROA.

3) $\mathrm{H}_{0}$ : NPL dan BOPO berpengaruh signifikan terhadap ROA.

$\mathrm{H}_{1} \quad$ : NPL dan BOPO tidak berpengaruh signifikan terhadap ROA.

\section{Metode Penelitian}

Menurut Sugiyono (2019:2) metode penelitian pada dasarnya merupakan cara ilmiah untuk mendapatkan data dengan tujuan dan kegunaan tertentu yang didasarkan pada ciri-ciri keilmuan, yaitu rasional, empiris, dan sistematis. Pada pendekatan penelitian ini menggunakan cara ilmiah empiris yang mana penelitian dilakukan dengan kriteria tertentu dan valid. Metode penelitian yang digunakan ialah pendekatan kuantitatif dengan metode deskriptif.

Melalui metode ini dilakukan pengumpulan data yang menggunakan strategi arsip, yaitu data dikumpulkan dari catatan atau basis data yang sudah ada. Sumber data yang digunakan dalam penelitian ini adalah data sekunder berupa laporan keuangan bank umum BUMN yang diperoleh dari website resmi Bursa Efek Indonesia (BEI) yaitu www.idx.co.id. 


\section{Prosedur Sampel}

Sebuah penelitian terikat oada populasi dan sampel. Menurut Sugiyono (2019:80) "populasi adalah wilayah generalisi yang terdiri atas objek atau subjek yang mempunyai kualitas dan karakteristik tertentu yang ditetapkan oleh peneliti untuk dipelajari dan kemudian ditarik kesimpulannya". Populasi dalam penelitian ini adalah seluruh Bank Umum BUMN yang terdaftar di Bursa Efek Indonesia tahun 2015-2020. Dan sampel adalah bagian dari jumlah dan karakteristik yang dimiliki oleh populasi tersebut. Dalam penelitian ini terdapat 4 Bank yang diteliti untuk 6 (enam) tahun periode, sehingga sample tersebut berjumlah 24 sampel.

\section{Operasionalisasi variabel}

Menurut Sugiyono (2019:80) "populasi adalah wilayah generalisi yang terdiri atas objek atau subjek yang mempunyai kualitas dan karakteristik tertentu yang ditetapkan oleh peneliti untuk dipelajari dan kemudian ditarik kesimpulannya". Populasi dalam penelitian ini adalah seluruh Bank Umum BUMN yang terdaftar di Bursa Efek Indonesia tahun 2015-2020.

Operasionalisasi veriabel diperlukan untuk menentukan jenis, indikator, serta skala dari variabel-variabel yang terkait dalam penelitian. Variabel-variabel yang terkait dalam penelitian ini adalah:

1) Variabel Bebas (Independent Variable)

Variabel independen sering disebut sebagai variable stimus, predictor, antecedent. Menurut Sugiyono (2019:39) Variabel bebas merupakan variabel yang mempengaruhi atau yang menjadi sebab perubahan atau timbulnya variabel dependen (terikat). Yang termasuk variabel bebas pada penelitian ini adalah :

a) Non-Performing Loan (NPL).

b) Biaya Operasional dan Pendapatan Operasional (BOPO)

2) Variabel Terikat (Dependent Variable)

Variabel dependen sering disebut sebagai variabel output, kriteria, dan konsekuen. Menurut Sugiyono (2019:39) variabel terikat adalah variabel yang dipengaruhi atau yang menjadi akibat karena adanya variabel bebas. Sesuai dengan masalah yang akan diteliti maka yang akan menjadi variabel terikat (dependent variabel) adalah return on assets (ROA).

\section{Teknik Analisis}

Jenis penelitian ini merupakan penelitian kuantitatif dengan teknik analisis regresi data panel atau analisis yang dilakukan dengan menggabungkan data time series dan cross-section atau sering disebut juga pooled data (pooling time series dan cross-section). Aplikasi yang digunakan untuk pengolahan data adalah Eview 9.

Periode diambil dari tahun 2015 sampai dengan 2020 dengan objek penelitian ini adalah Bank BUMN yang terdaftar di BEI. Data yang digunakan merupakan data sekunder yang berupa laporan keuangan.

Teknik analisis dituliskan dengan model sebagai berikut :

$$
\mathrm{Y}_{\mathrm{it}}=\beta_{1}+\beta_{2} \mathrm{X}_{2 \mathrm{it}}+\beta_{2} \mathrm{X}_{2 \mathrm{it}}+\mu_{\mathrm{it}} ; \quad \mathrm{i}=1,2,3,4 \quad \mathrm{t}=1,2, \ldots ., 20
$$

$$
\begin{aligned}
& \text { Keterangan : } \\
& \begin{array}{ll}
\mathrm{i} \quad=\text { banyaknya observasi } \text { cross-section } \\
\mathrm{t} \quad=\text { banyaknya tahun periode waktu }
\end{array}
\end{aligned}
$$




\section{Hasil Penelitian dan Pembahasan Statistik Deskriptif}

Pada tabel 4.1 dirangkum semua variabel yang digunakan dalam penelitian ini. Dengan menggunakan sampel dari perusahaan perbankan yang berstatus BUMN yaitu 4 (empat) Bank pada periode 2015-2020 yang telah menyerahkan laporan tahunan secara lengkap dan data tersebut di publikasi secara umum.

Tabel 2. Statistik Desktriptif

\begin{tabular}{|l|c|c|c|c|}
\hline & Minimum & Maximum & Mean & Std. Deviation \\
\hline ROA & 0.001300 & 0.041900 & 0.023888 & 0.010840 \\
\hline NPL & 0.016000 & 0.047800 & 0.028292 & 0.007924 \\
\hline BOPO & 0.664800 & 0.981200 & 0.769896 & 0.089826 \\
\hline
\end{tabular}

Sumber : diolah penulis (2021)

Berdasarkan tabel di atas dapat dilihat bahwa ROA, NPL, dan BOPO memiliki mean lebih besar dari standar deviasi yang dapat diartikan sebagaimana data variabel tersebut berkelompok atau tidak bervariasi.

Dalam pengolahan data dengan menggunakan teknin analisis regresi data panel, dilakukan beberapa tahapan untuk mencari hubungan antar variabel independen dan dependen menggunakan software Eview 9 dan didapatkan ringkasan seperti pada tabel 4.2 di bawah ini.

\section{Hasil Analisis Regresi Data Panel}

Berdasarkan pengujian yang telah dilakukan, metode data panel yang sesuai adalah metode Random Effect.

Tabel 3 Hasil Uji Regresi dengan Metode Random Effect, a = 5 \%

\begin{tabular}{lcccc}
\hline Variabel & Koefisien $\beta$ & $\mathrm{P}_{\text {value }}$ & $\mathrm{t}_{\text {hitung }}$ & Keterangan \\
\hline Konstanta $(\mathrm{C})$ & 0.110755 & 0.0000 & 14.60491 & \\
NPL $\left(\mathrm{X}_{1}\right)$ & 0.074156 & 0.5701 & 0.576915 & Tidak Signifikan \\
BOPO $\left(\mathrm{X}_{2}\right)$ & -0.115879 & 0.0000 & -8.497554 & Signifikan \\
\hline R-squared & 0.933555 & & & \\
F-statistic & 147.5253 & & & \\
Prob (F Statistik) & 0.000000 & & & \\
\hline
\end{tabular}

Sumber : diolah penulis (2021)

Berdasarkan tabel 4.1 didapat sebuah persamaan seperti berikut :

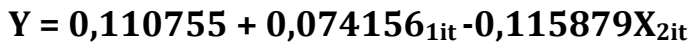

Pada persamaan tersebut dapat terlihat bahwa nilai konstanta yang di hasilkan adalah sebesar 0.110755 yang diperoleh menunjukkan bahwa NPL dan BOPO dianggap tetap atau konstan, maka terjadi perubahan variabel dependen sebesar 0.110755 , yang diartikan ROA yang dimiliki Bank BUMN akan mengalami kehaikan sebesar 0.110755 .

Berdasarkan hasil uji statistik, variabel NPL tidak berpengaruh secara signifikan terhadap Return On Assets (ROA) pada Bank BUMN dengan nilai p-value yang diperoleh sebesar 0.5701 lebih besar dari $\alpha$ atau tingkat kepercayaan sebesar 0.05. Sebagian besar penelitian mengindikasikan bahwa jika NPL naik maka ROA akan turun, atau dengan kata lain berpengaruh signifikan negatif, namun hasil penelitian ini berbeda dari penelitian penelitian sebelumnya. Hal ini disebabkan oleh fenomena data laporan keuangan bank BUMN pada waktu periode penelitian dinyatakan bahwa ternyata kenaikan atau penurunan NonPerforming Loan (NPL) tidak memberikan dampak apapun terhadap Return On Assets (ROA) 
pada Bank BUMN, sehingga Bank BUMN lebih leluasa dalam mengambil kebijakan penyaluran kredit nya kepada nasabah.

BOPO memiliki pengaruh yang signifikan dan memiliki arah yang negatif dengan ROA dengan tingkat probabilitas sebesar 0.0000 atau dapat dikatakan dibawah signifikansi level 0,05. Dengan tingkat koefisien -0.115879 , menunjukkan bahwa ada pengaruh negatif antara BOPO dengan ROA bank BUMN. Faktor yang menyebabkan variabel BOPO memiliki koefisien negatif dan berpengaruh secara signifikan terhadap ROA adalah cerminan dari tingginya rasio BOPO pada periode penelitian yang menjelaskan bahwa tingginya rasio tersebut mempengaruhi kesehatan bank BUMN pada masa mendatang dan masa berjalan. Apabila manajemen bank BUMN dapat melakukan efisiensi pada BOPO maka ROA akan meningkat. Efisiensi dapat dilakukan pada biaya biaya opersaional seperti biaya eksternal terutama pada biaya kantor dan biaya promosi.

Hasil pengujian BOPO pada penelitian ini sejalan dengan penelitian Nurismalatri (2019), Aminar (2017), Christiano dkk (2014), Vernanda dkk (2016), Pratiwi \& Wiagustini (2015), Sabir dkk (2012), menyatakan dalam sektor perbankan pada umumnya terjadi hubungan negatif antara biaya operasional dan pendapatan operasional (BOPO) dengan profitabilitas. BOPO menunjukkan seberapa besar bank dapat menekan biaya operasionalnya di satu pihak, dan seberapa besar kemampuan untuk meningkatkan pendapatan operasional di pihak lain. BOPO memiliki pengaruh terhadap kinerja perbankan karena menunjukkan seberapa besar bank dapat melakukan efisiensi terhadap biaya operasional yang dikeluarkan. Semakin kecil rasio BOPO, berarti semakin efisien biaya operasional yang dikeluarkan bank yang bersangkutan sehingga kemungkinan yang lebih besar bagi bank untuk mendapatkan keuntungan yang lebih dan menunjukkan bahwa bank tidak berada dalam kondisi bermasalah.

\section{Keterbatasan dan Agenda Penelitian Mendatang}

Terdapat keterbatasan dalam penelitian ini, yaitu dimana sampel penelitian ini hanya menggunakan bank BUMN yang ber periode 6 (enam) tahun sehingga kemungkinan tidak dapat memperlihatkan kemajuan periode kinerja pada banyak bank umum yang ada di Indonesia. Penelitian mendatang disarankan untuk menggunakan sampel yang lebih bervariasi dengan menambah periode atau mengganti kriteria dengan bank umum swasta yang terdapat di Indonesia.

\section{Kesimpulan}

Hasil penelitian menunjukkan bahwa BOPO sangat berpengaruh atas tinggi rendahnya profitabilitas perbankan. Sedangkan NPL pada periode ini tidak berpengaruh terhadap peningkatan dan penurunan ROA. BOPO berpengaruh negatif signifikan disebabkan dari adanya pengelolaan pembiayaan yang efisien atau tidak sehingga menunjukkan perubahan pada ROA, semakin kecil nilai BOPO maka semakin meningkat nilai laba perusahaan.

\section{Daftar Pustaka}

Anwar, M. (2019). Dasar-dasar Manajemen Keuangan. Jakarta : KENCANA.

Christiano. M., Tommy. P., \& Saerang. I. (2014). Analisis Terhadap Rasio-Rasio Keuangan Untuk Mengukur Profitabilitas Pada Bank-Bank Swasta Yang Go Public Di Bursa Efek Indonesia. Jurnal EMBA. 2(4). 817-830.

Dewi. A. S. (2018). Pengaruh CAR, BOPO, NPL, NIM, dan LDR Terhadap ROA Pada Perusahaan Di Sektor Perbankan Yang Terdaftar Di BEI Periode 2012-2016. Jurnal Pundi. 1(3). 223236. 
Ghozali, I. (2017). Ekonometrika. Semarang : Badan Penerbit - Universitas Diponegoro.

Husnan, S., \& Pudjiastuti E. (2015). Dasar-dasar Manajemen Keuangan. Yogyakarta : UPP STIM YKPN.

Kasmir. (2014). Bank dan Lembaga Keuangan Lainnya. Jakarta : PT Rajagrafindo Persada.

Kasmir. (2017). Analisis Laporan Keuangan. Jakarta : PT Rajagrafindo Persada.

Munawir. (2014). Analisa Laporan Keuangan. Ygyakarta : LIBERTY.

Nachrowi, D., \& Usman, H. (2006). Ekonometrika. Jakarta : Lembaga Penerbit Fakultas Ekonomi Universitas Indonesia.

Ningtyas. C. P., Darminto., \& Husaini. (2013). Perbandingan Kinerja Keuangan Bank Konvensional dan Bank Syariah Berdasarkan Analisis Rasio Keuangan. Jurnal Akuntansi. Fakultas Ekonomi dan Bisnis Universitas Brawijaya Malang.

Nugroho. D., Mangantar. M., \& Tulung. J. E. (2019). Pengaruh CAR, BOPO, NIM, dan NPL Terhadap ROA Industri Bank Umum Swasta Nasional Buku 3 Periode 2014 - 2018. Jurnal EMBA. 7(3). 4222-4229.

Nurismalatri. (2019). Sharia Banks' Performance In Indonesia : A Panel Model Approach. Jurnal Sekuritas. 2(2). 131-140.

Pratiwi. L. P. S. W., \& Wiagustini. N. L. P. (2015). Pengaruh CAR, BOPO, NPL dan LDR Terhadap Profitabilitas. E-Jurnal Manajemen Unud. 5(4). 2137-2166.

Purwoko. D., \& Sudiyatno. B. (2013). Faktor-Faktor yang Mepengaruhi Kinerja Bank. Jurnal Bisnis \& Ekonomi. 20(1). 25-39.

Santoso, S. (2018). Statistik Parametrik. Jakarta : PT Elex Media Komputindo.

Sugiyono. (2017). Metode Penelitian. Bandung : ALFABETA.

Sutrisno. (2013). Manajemen Keuangan. Yogyakarta : EKONISIA.

Vernanda. S. D., \& Widyarti. E. T. (2016). Analisis Pengaruh CAR, LDR, NPL, BOPO, dan SIZE Terhadap ROA. Journal of Management. 5(3). 1-13.

Warsa. N. M. I. U. P., \& Mustanda. I. K. (2016). Pengaruh CAR, LDR dan NPL Terhadap ROA Pada Sektor Perbankan Di Bursa Efek Indonesia. Jurnal Manajemen Unud. 5(5). 2842-2870.

Yanti. N. (2013) Analisis Kinerja Perusahaan Perbankan. Jurnal KBP. 1(2). 161-180.

Yuliana. A. (2014). Pengaruh LDR, CAR, ROA dan NPL Terhadap Penyaluran Kredit Pada Bank Umum Di Indonesia Periode 2008 - 2013. Jurnal Dinamika Manajemen. 2(3). 169-186. 